\title{
Pelaksanaan Investasi Sektor Pariwisatapulau-Pulau Kecil Di Kabupaten Pesisir Selatan
}

\author{
Divya Koemala \\ Universitas Indonesia \\ divyakoemala@gmail.com
}

\begin{abstract}
Abstrak. Indonesia sebagai negara berkembang sedang melakukan banyak aktivitas salah satunya dalam kegiatan penanaman modal atau investasi terutama di sektor pariwisata di Kabupaten Pesisir selatan yang sedang giatnya berkembang. Dalam skripsi ini perumusan masalah yang dibahas adalah: a) bagaimana pelaksanaan pengelolaan investasi dalam sektor pariwisata pulau-pulau kecil di Kab.Pesisir Selatan. b) apa kendala yang dihadapi dalam pelaksanaan investai dalam sektor pariwisata pulau-pulau kecil di Kab.Pesisir Selatan serta upaya dalam mengatasi kendala tersebut. Metode penelitian yang digunakan adalah yuridis empiris yaitu pendekatan terhadap masalah yang ada dengan jalan memahami hokum positif dari suatu objek penelitian dan bagaimana kenyataan atau praktiknya dilapangan. Kemudian dianalisis secara kualitatif dan dijabarkan secara deskriptif. Hasil penelitian memperlihatkan bahwa: a) pelaksanaan investasi pariwisata pulau-pulau kecil di Kab.Pessel telah dilaksanakan sesuai dengan UUPenanaman Modal dan UUkepariwisataan. Dalam pelaksanaannya terdapat satu perusahaan penanam modal asing dan lebih dari 12 orang penanam modal dalam negeri yang berinvestasi di pariwisata pulau. Dalam kegiatan investasi di pariwisata pulau-pulau kecil adalah dalam bidang usaha daya tarik wisata, usaha jasa transportasi pariwisata, jasa perjalanan wisata, jasa makanan dan minuman, usaha penyediaan akomodasi, dan usaha wisata tirta. b) dalam pelaksanaannya terdapat kendala yaitu: banyaknya tanah yang tidak terdaftar, calon investor yang tidak memenuhi persyaratan yang telah di tentukan, kurangnya kesadaran masyarakat akan pengembangan investasi terutama di sektor pariwisata, dan minimnya fasilitas prasaran di Pesisir Selatan. Solusi yang sedang dilakukan pemerintah setempat adalah dengan penyuluhan dan pembinaan pada masyarakat setempat untuk mau mendaftarkan tanahnya, mengurusi izin dan terbuka akan kegiatan investasi dan pariwisata, mempermudah pelayanan perizinan dan non perizinan dan melakukan koordinasi lintas sektor antar instansi untuk memperbaiki dan memaksimalkan prasarana.
\end{abstract}

\section{Kata Kunci: Investasi, Pariwisata, Pulau}

Abstract. Indonesia as a developing country is doing a lot of activities in Pesisir Selatan that is being actively growing. In this skripsi, the formulation of the problem are: a) how the government of Kab.Pesisir Selatan manage the investation in tourism of small islands. b) what is the government challange involved in investment in tourism of small Islands in Kab. Pesisir Selatan. Research methods used are juridical empirical, that is the existing approach with an understanding positif law of an object and how reality in the field. Then analyzed qualitatively and described descriptively. The results showed that: a) The basic investigation in Kab.Pessel has been implemented in accordance with UU Penanaman Modal and UU Kepariwisataan. In practice it finds one investment company and more than 12 domestic investors who invest in insland tourism. Activity that involved in investing in small islands tourism are tourist attraction transportation, tourism and travel agency, food and beverage, providing accommodatin and other tourism bussiness activity. b) in the implementation there is obstacles such as: whether unregistered land, potential investors who do not meet the requirements, lack of people awareness about investation commonly in tourism field, and low in facility in Pesisir Selatan. The government's ongoing solution is to counseling and coaching local communities to register their land, 
take care of permits and be open to investing activities and tourism, make it easier permit service and non permit service and coordinating inter-sectoral services to improve facilities.

Keywords: Investation, Tourism, Island

\section{PENDAHULUAN}

\section{A. Latar Belakang}

Manusia sebagai makhluk sosial tidak dapat terlepas dari kehidupan bersaa dengan manusia lainnya. Manusia sangat bergantung pada banyak sekali kebutuhan. Begitu pula Negara Indonesia, negara tidak dapat berdiri sendiri dan membutuhkan bantuan baik langsung dari masyarakat dalam negeri maupun dari negara lain.

Indonesia sebagai negara berkembang merupakan negara yang sedang melakukan proses pembangunan dari segala sektor dapat kita rasakan terlebih pada sektor pembangunan perekonomian. Dalam melakukan pembangunan nasional tersebut tentulah membutuhkan pendanaan yang besar sebagai modal melakukan pembangunan. Modal itu sendiri juga dibutuhkan untuk mengelola sumber daya alam dan potensi ekonomi yang berada di bawah otoritas negara.

Adapun salah satu sumber dana utama guna memenuhi kebutuhan dana yang besar dalam melaksanakan pembangunan tersebut dapat diperoleh melalui kegiatan penanaman modal atau yang lebih dikenal dengan kata investasi. Pada era globalisasi ini kegiatan investasi merupakan hal yang cukup menguntungkan bagi negara bila diatur dengan baik. Investasi yang akan dilakukan baik oleh investor domestic maupun investor asing sudah selayaknya mendapatkan perhatian yang khusus dari pemerintah guna kepentingan pembangunan dan negara.

Pengertian investasi menurut Kamus Besar Bahasa Indonesia disebutkan investasi berarti "Pertama penanaman uang atau modal disuatu perusahaan atau proyek untuk tujuan memperoleh keuntungan; dan kedua jumlah uang atau modal yang ditanamkan. Sebagai suatu hal yang diatur dalam peraturan perundang undangan di Indonesia. Investasi juga memiliki pengertian sesuai dengan undang undangnya. Menurut Undang-Undang Nomor 25 Tahun 2007 Tentang Penanaman Modal (selanjutnya disebut UUPM) dikemukakan bahwa. "Penanaman modal adalah segala bentuk kegiatan penanaman modalbaik oleh penanam modal dalam negeri maupun penanam modal asing untuk melakukan usaha di wilayah Republik Indonesia"

Dalam pasal 3 ayat (2) UUPM juga telah menjelaskan mengenai tujuan penyelenggaraan investasi yaitu :

a) Meningkatkan pertumbuhan ekonomi nasional;

b) Menciptakan lapangan kerja;

c) Meningkatkan pembangunan ekonomi berkelanjutan;

d) Meningkatkan kemampuan daya saing dunia usaha nasional;

e) Meningkatkan kapasitas dan kemampuan teknologi nasional;

f) Mendorong pengembangan ekonomi kerakyatan;

g) Mengolah ekonomi potensial menjadi kekuatan ekonomi riil dengan menggunakan dana yang berasal baik dari dalam negeri maupun luar negeri;

h) Meningkatkan kesejahteraan masyarakat;

Salah satu sektor yang sangat berperan dalam pembangunan di Indonesia adalah sektor pariwisata. Sektor pariwisata di Indonesia saat ini dinilai efektif dalam penambahan kebutuhan pembangunan dari segala sisi terutama bagi devisa negara. Pertumbuhan kebutuhan manusia akan pariwisata yang indah dan menyegarkan menyebabkan sektor ini dinilai mempunyai prospek yang sangat baik dimasa yang akan datang serta dianggap mampu untuk menghidupkan perekonomian masyarakat sekitar. Keragaman budaya Indonesia sesuai dengan daerah pariwisatanya menjadikan suatu keunikan yang juga dapat memberikan sumbangan yang besar membantu perekonomian negara. 
Sektor pariwisata merupakan suatu bidang usaha yang dapat terus diperbaharui atau direnovasi, diremajakan dirawat serta dilengkapi kebutuhan penunjangnya demi kenyamanan konsumen melakukan kegiatan dibidang pariwisatanya. Sektor pariwisata merupakan investasi yang secara otomatis mempermudah perputaran barang dan jasa pelayanan di tempat wisata apalagi bila di tunjang dengan fasilitas pendukung lainnya.

Indonesia dikenal dengan destinasi pariwisata yang terkenal karena keindahannya. Salah satu provinsi yang sangat terkenal keindahan alamnya adalah Sumatera Barat. Mulai dari keindahan alam yang berbalut warna hijau sampai dengan pasir putih berselimut air biru tersedia di Sumatera Barat. Wisata budaya adat juga dapat dinikmati sembari menikmati keindahan alam. Berbagai perbedaan kuliner juga menjadi daya tarik tersediri. Hal ini menjadikan Sumatera Barat sebagai provinsi yang membuka luas kesempatan ber-investasi atas keindahan serta keunikannya.

Wisata yang mulai mengalami peningkatan yang cukup signifikan adalah wisata bahari yaitu pulau. Pulau yang dalam hal ini yaitu pulau-pulau kecil sesuai dengan yang di dalam Undang Undang Nomor 27 Tahun 2007 jo Undang-Undang Nomor 1 Tahun 2014 Tentang Pengelolaan Wilayah Pesisir dan Pulau-Pulau Kecil (selanjutnya disebut UUPWP3K). Menurut Pasal 1 angka 3 UUPWP3K "Pulau Kecil adalah pulau dengan luas lebih kecil atau sama dengan $2.000 \mathrm{~km} 2$ (dua ribu kilometer persegi) beserta kesatuan ekosistemnya.

Sumatera Barat memiliki kawasan laut seluas 186.500 kilometer persegi dengan garis pantai mencapai 1.973.25 kilometer. Total pulau-pulau kecil di Sumatera Barat yang berada di tujuh daerah adalah sebanyak 185 pulau. Tujuh daerah di Sumatera Barat memiliki wilayah perairan dan pulau-pulau yaitu Kabupaten Pesisir Selatan. Kota Padang. Kepulauan Mentawai. Padang Pariaman. Kota Pariaman. Agam dan Pasaman Barat. Kabupaten Pesisir Selatan memiliki 4.860.22 kilometer persegi. Kepulauan Mentawai 6.011.35 kilometer persegi. Kota Padang
389.05 kilometer persegi. Padang Pariaman 420.46 kilometer persegi. Kota Pariaman 55.85 kilometer persegi. Agam 205.73 kilometer persegi.dan Kabupaten Pasaman Barat 1.807.77 kilometer persegi.

Kabupaten Pesisir Selatan merupakan kabupaten yang sedang berkembang dan mulai dikenal oleh wisatawan baik domestic maupun mancanegara. Tercatat ada sebanyak 47 pulau pulau kecil yang memiliki potensi yang dapat dikembangkan dengan segala keindahannya di Kabupaten Pesisir Selatan yang menjadi daya tarik wisatawan dan investor untuk menanamkan modal di Pesisir Selatan. 20 pulau diantaranya tercatat dalam data objek wisata unggulan Kabupaten Pesisir Selatan menurut Dinas Pariwisata Provinsi Sumatera Barat.

Dalam Pasal 5 UU No 1 Tahun 2014 tentang Pengelolaan Wilayah Pesisir dan PulauPulau Kecilmenjelaskan bahwa "Pengelolaan wilayah pesisir dan pulau-pulau kecil meliputi kegiatan perencanaan pemanfaatan pengawasan dan pengendalian terhadap interaksi manusia dalam memanfaatkan sumber daya pesisir dan pulau-pulau kecil serta proses alamiah secara berkelanjutan dalam upaya meningkatkan kesejahteraan masyarakat dan menjaga keutuhan Negara Kesatuan Republik Indonesia." Berdasarkan pasal tersebut dapat disimpulkan bahwa pulau-pulau di Sumatera Barat juga memiliki peranan dalam meningkatkan kesejahteraan masyarakat Indonesia. Pemeritah daerah Provinsi Sumatera Barat juga serius dengan mengajukan RancanganPerda (Ranperda)Provinsi Sumatera Barat mengenai Zonasi Wilayah Pesisir dan Pulau-Pulau Kecil.

Namun sebagian besar objek wisata pulau kecilyang sangat berpotensi di Sumatera Barat belum dikelola dengan baik. Kurang fasilitas sulit akomodasi serta kurang dukungan dari masyarakat yang masih menganggap negatif terhadap pariwisata menurunkan nilai dari objek wisata itu sendiri. Permasalahan lainnya di bidang pariwisata pulau di Pesisir Selatan juga terkait hal hal kecil namun mengganggu seperti hal nya tarif akomodasi yang mahal, biaya parker pemalakan atau pungutan liar serta 
tarif rumah makan yang tidak wajar membuat pariwisata Sumatera Barat di cap buruk oleh wisatawan. Buruknya lagi akan berdampak pada turunnya minat investor untuk berinvestasi di pariwisata Sumatera Barat.

Sebagai bentuk upaya pelaksanaan koordinasi antara pemerintah pusat dengn pemerintah daerah terhadap pemberian fasilitas yang diberikan oleh penanam modal, pemerintah telah mengeluarkan Peraturan Pemerintah Nomor 45 Tahun 2008 Tentang Pedoman Pemberian Intensif dan Pemberian Kemudahan Penanam Modal di Daerah. Dalam hal ini peraturan tersebut dijadikan sebagai dasar pelaksanaannya di daerah untuk membuat suatu pengaturan dalam rangka meningkatkan dan mengembangkan investasi di daerah.

Peraturan pemerintah tersebut juga sesuai dengan Pasal 278 ayat (2) Undang-Undang Nomor 23 Tahun 2014 Tentang Pemerintahan Daerah yaitu bahwa "penyelenggara Pemerintahan Daerah dapat memberikan intensif dan/atau kemudahan kepada masyarakat dan/atau investor yang diatur dalam Perda dengan berpedoman pada ketentuan peraturan perundang-undangan"

Berdasarkan latar belakang diatas.penulis tertarik untuk melakukan penelitian dengan judul "PELAKSANAAN INVESTASI SEKTOR PARIWISATA PULAU PULAU KECIL DI KABUPATEN PESISIR SELATAN".

\section{B. Perumusan Masalah}

Berdasarkan ruang lingkup permasalahan diatas, penulis merumuskan permasalahan yang akan diteliti, yaitu:

1. Bagaimana Pelaksanaan Pengelolaan Investasi Dalam Sektor Pariwisata PulauPulau Kecil di Kabupaten Pesisir Selatan?

Apa Kendala yang dihadapi dalam Pelaksanaan Pengelolaan Investasi dalam Sektor Pariwisata Pulau-Pulau Kecil di Kabupaten Pesisir Selatan Serta Solusi Dalam Mengatasi Kendala Tersebut?

\section{HASIL PENELITIAN \\ PEMBAHASAN \\ 1. Pelaksanaan Pengelolaan Investasi Pariwista Pulau-Pulau Kecil Di Kabupaten Pesisir Selatan}

A. Mekanisme Pelaksanaan Investasi di Sektor Pariwisata Pulau-Pulau Kecil di Kab. Pesisir Selatan

Mekanisme pelaksanaan investasi di sektor pariwisata di DPMPPTSP Pesisir Selatanpada umumnya sama dengan pelayanan perizinan di sektor lainnya. Mengenai pelaksanaan pelayanan perizinan dan non perizinan di Kabupaten Pesisir Selatan telah di atur dalam Keputusan Bupati Pesisir Selatan No: 570/285/Kpts/BPT-PS/2017 Tentang Penetapan Standar Operasional Prosedur (SOP) Pelayanan Perizinan dan Non Perizinan Pada Dinas Penanaman Modal Dan Pelayanan Perizinan Terpadu Satu Pintu. Jenis pelayanan penanaman modal di DPMPPTSPPesisir Selatan di kelompokkan sebagai berikut:

Pelayanan Perizinan dibidang Penanaman Modal

1. Pelayanan Izin Prinsip Penanaman Modal

a. Izin Prinsip Penanaman Modal

b. Izin Prinsip Perluasan Penanaman Modal

c. Izin Prinsip Perubahan Penanaman Modal

d. Izin Usaha Penanaman Modal

e. Izin Usaha Perluasan Penanaman Modal

f. Izin Usaha Perubahan Penanaman Modal

g. Izin Usaha Penggabungan Penanaman Modal

2. Pelayanan Izin Teknis

a. Izin Mendirikan Bangunan (IMB)

b. Surat Izin Tempat Usaha (SITU)

c. Surat Izin Usaha Perdagangan (SIUP)

d. Izin Lingkungan

e. Izin-Izin lain sesuai dengan sektor kebutuhan untuk pelaksanaan penanaman modal serta rekomendasi Organisasi Perangkat Daerah (OPD) teknis

Dalam hal ini, izin lain yang dimaksudkan adalah Perizinan dibidang Pariwisata, yaitu: 
1. Tanda Daftar Usaha Jasa Perjalanan Wisata

2. Tanda Daftar Usaha Jasa Penyediaan Akomodasi

3. Tanda Daftar Usaha Jasa Makanan dan Minuman

4. Tanda Daftar Usaha Jasa Kawasan Pariwisata

5. Tanda Daftar Usaha Jasa Transportasi Pariwisata

6. Tanda Daftar Usaha Daya Tarik Wisata

7. Tanda Daftar Usaha Jasa Penyelenggaraan Kegiatan Hiburan dan Rekreasi

8. Tanda Daftar Usaha Jasa Pramuwisata

9. Tanda Daftar Usaha Penyelenggaraan Pertemuan, Perjalanan Intensif, Konverensi dan Pameran

10. Tanda Daftar Jasa Konsultan Wisata

11. Tanda Daftar Usaha Jasa Informasi Pariwisata

12. Tanda Daftar Usaha Wisata Tirta

13. Tanda Daftar Usaha Jasa Spa

Masing-masing bentuk perizinan memilik syarat yang harus dipenuhi oleh pemohon izin. Terkait syarat-syarat khusus tentu saja sesuai dengan jenis perizinan yang dimohonkan oleh pemohon, namun secara umum berikut persyaratannya:

1. Surat permohonan

2. Profil perusahaan bagi perusahaan yang berbadan hukum

3. Foto copy akta pendirian perusahaan yang berbadan hukum, atau akta pendirian badan usaha yang mencantukman usaha di bidang pariwisata termasuk maksud dn tujuannya, atau fotocopy kartu tanda penduduk untuk pengusaha perseorangan

4. Fotocopy Nomor Pokok Wajib Pajak (NPWP)

5. Fotocopy SITU bila dipersyaratkan

6. Fotocopy IMB bila memiliki bangunan

7. Izin lingkungan bila dipersyaratkan

8. Status tanah bila dipersyaratkan

9. Rekomendasi OPD teknis

10. Rekomendasi penata atau pemanfaatan ruang bila dipersyaratkan

11. Pernyataan yang menjamin kebenaran data dan dokumen yang diserahkan

12. Materai Rp6.000 sebanyak dua (2) lembar
Berdasarkan pernyataan Nofalina, dalam pelaksanaan investasi DPMPPTSP Pesisir Selatan hanya mengeluarkan izin sesuai dengan permohonan yang di ajukan oleh pemohon. Segala persyaratan serta rekomendasi OPD setempat diurus oleh pemohon langsung misalnya izin lingkungan baik skala besar maupun kecil di urus ke Dinas Lingkungan Hidup Pesisir Selatan. Ketika semua berkas telah lengkap maka DPMPPTSP akan memproses dan mengeluarkan izin yang diinginkan.Terkait bidang pariwisata, apabila telah mengurusi jenis izin pariwisata maka tidak lagi harus mengurusi izin penanaman modal.

Menurut Nofalina juga bahwa segala bentuk kegiatan yang memerlukan izin yang ada di Pesisir Selatan pada umumnya sudah memiliki izin. Apabila ada yang belum memiliki izin maka akan dihimbau untuk memohonkan izin karena pemerintah sudah mempermudah segala bentuk perizinan kecuali yang diatur untuk membayar retribusi.

\section{B. Investasi di Sektor Pariwisata Pulau- Pulau Kecil di Kabupaten Pesisir Selatan}

Kegiatan investasi di sektor pariwisata pulau di Pesisir Selatan tergolong rendah. Hal ini dijelaskan oleh Isfildi bahwa terbukti dengan hanya ada satu perusahaan asing yang menanamkan modalnya di Pesisir Selatan yaitu di Pulau Cubadak oleh PT. Bintang Paradiso dengan membangun 12 Cottage di atas pulau tersebut dalam usaha penyedia akomodasi pariwisata. Adapun rencana di Pulau Marak dan pulau lainnya masih dalam tahap negosiasi.

Isfildi menyatakan jika saat ini pulau-pulau lain masih belum dikelola dengan baik. Investor asing yang melakukan kegiatan investasi di Pesisir Selatan hanya PT. Bintang Paradiso tersebut. Sejauh ini pulau-pulau dikelola oleh masyarakat hukum adat setempat. Pengelolaan di Pulau Setan, Pulau Pagang dan Swarnadwipa serta Pulau Cingkuak itu adalah investor dalam negeri berupa perseorangan bukan badan usaha. Hal ini sesuai dengan pengertian penanam modal dalam negeri menurut Pasal 1 angka 5 Undang-Undang No.25 Tahun 2007 tentang Penanaman Modal bahwa: 
"penanam modal dalam negeri adalah perseorangan warga negara Indonesia, badan usaha Indonesia, Negara Republik Indonesia, atau daerah yang melakukan penanaman modal di wilayah negara Republik Indonesia."

Kemudian adanya BAB IV yang mengatur tentang bentuk badan usaha dan kedudukannya dalam Pasal 5 menjelaskan bahwa:

"penanam modal dalam negeri dapat dilakukan dalam bentuk badan usaha yang berbentuk badan hukum, tidak berbadan hukum atau usaha perseorangan, sesuai degan ketentuan peraturan perundang-undangan."

Menurut Aciak, dalam hal pariwisata, investor dalam negeri menanamkan modal atau uangnya dalam bentuk menyediakan jasa wisata bahari seperti jasa sewa atau peminjaman peralatan renang, selam dan fasilitas wisata air sepertijetski, flying fish, banana boat, rolling boat, flying fox, snorkelingdan fasilitas foto underwater serta jenis wahana lainnya untuk dinikmati pengunjung pulau yang sedang berwisata serta jasa perjalanan wisata atau penyedia akomodasi pariwisata. Investor dalam negeri sendiri sudah mulai banyak membangun seperti di Pulau Pagang, Pulau Cingkuak dan Pulau Setan namun masih secara perseorangan tidak berbentuk badan hukum.

Lebih lanjut Aciak menjelaskan bahwa jika mengkaji investasi pariwisata sebenarnya tidak bisa hanya dilihat dari objek pariwisatanya saja misalnya apasaja yang ada di suatu pulau, namun harus dari hal-hal yang menunjang pariwisata tersebut, sehingga kegiatan investasi di pariwisata tergantung selera dari pada investor. Hal ini seperti yang disebutkan dalam penjelasan Pasal 14 ayat (1) Undang-Undang Nomor 10 Tahun 2009 tentang Kepariwisataan bahwa usaha pariwisata meliputi, antara lain:

a) Adaya tarik wisata, yiatu usaha yang kegiatannya mengelola daya tarik wisata alam, daya tarik wisata budaya, dan daya tarik wisata buatan/binaan manusia;

b) kawasan pariwisata, yaitu usaha yang kegiatannya membangun dan/atau mengelola kawasan dengan luas tertentu untuk memenuhi kebutuhan pariwisata;

c) jasa transportasi wisata, usaha khusus yang menyediakan angkutan untuk kebutuhan dan kegiatan pariwisata, bukan angkutan transpoortasi reguler/umum;

d) jasa perjalanan wisata, yiatu usaha biro perjalanan wisata dan usaha agen pariwisata. Usaha biro perjalanan pariwisata meiputi usaha penyediaan jasa perencanaan perjalanan dan/atau jasa pelayanan dan penyelenggaraan pariwisata, termasuk penyelenggara wisata ibadah. Usaha agen perjalanan wisata meliputi usaha jasa pemesanan sarana, seperti pemesana tiket dan pemesanan akomodasi serta pengurusan dokumen perjalanan;

e) jasa makan dan minuman, yaitu usaha jasa pneydia makanan dan minuman yang dilengkapi dengan peralatan dan perlengkapanuntuk proses pembuatan dapat berupa restoran, kafe, jasa boga, bar/kedai minum;

f) penyediaan akomodasi, yaitu usaha yang menyediakan pelayanan penginapan yang dapat dilengkapi dengan pelayanan wisata lainnya. Untuk penyeiaan akomodasi dapat berupa hotel, vila, pondok wisata, bumi perkemahan, persinggahan karavan, dan akomodasi lainnya yang digunakan untuk tujuan wisata;

g) penyelenggaraan kegiatan hiburan dan rekreasi, yaitu usaha yang ruang lingkup kegitannya berupa usaha seni pertunjukan, arenapermainan, karaoke, bioskop, serta kegiatan hiburan dan rekreasi lainnya yang bertujuan untuk pariwisata;

h) penyelenggaraaan pertemuan, perjalanan insentif,konferensi dan pameran, yaittu usaha yang memberikan jasa bagi suatu pertemuan sekelompok orang, menyelenggarakan perjalanan bagi karyawan dan mitra usaha sebagai imbalan atas prestasinya, serta menyelenggarakan pameran dalam rangka menyebarluaskan informasi dan promosi suatu barang dan jasa yang berskala nasional, regional, dan internasional; 
i) jasa informasi pariwisata, yaitu usaha yang menyediakan data, berita, feature, foto, video, dan hasil penelitian mengenai kepariwisataan yang disebarkan dalam bentuk bahan cetak dan/atau elektronik;

j) jasa konsultasi pariwisata, yaitu usaha yang mmenyediakan saran dan rekomendasi mengenai studi kelayakan, perencanaan, pengelolaan usaha, penelitian dan pemasaran di bidang kepariwisataan;

k) jasa pramuwisata, yiatu usaha yang menyediakan dan.atau mengoordinasikan tenaga pemandu wisata untuk memenuhi kebutuhan wisatawan dan/atau kebutuhan biro perjalnan wisata;

1) wisata tirta, yaitu usaha yang menyediakan wisata dan olahraga air, termasuk penyediaan sarana dan prasarana serta jasa lainnya yang dikelola secara komersial diperaian laut, pantai, sungai, danau dan waduk;dan

m) spa, yaitu usaha perawatan yang memberikan layanan dengan metode kombinasi terapi air, terapi aroma, pijat, rempah-rempah, layanan makanan/minuman sehat, dan olah aktivitas fisik dengan tujuan menyeimbangkan jiwa dan raga dengan tetap memperhatikan tradisi dan budaya Bangsa Indonesia.

Menurut Gusri Efendi, kegiatan yang ada dalam pariwisata pulau memang dilakukan secara perseorangan namun juga membentuk suatu kelompok usaha bukan berbadan hukum. Baik gusri maupun pengelola usaha wisata lainnya memang belum berniat menjadikan persekutuannya menjadi badan usaha atau badan hukumkarena masyarakat beralasan bahwahal tersebut cenderung sulit pengurusannya serta ditakutkan terjadi batasanbatasan tertentu sehingga tak lagi bisa melakukan usaha bersama berdasarkan kekeluargaan.Bagi masyarakat yang terlibat, pariwisata sangat membantu perekonomian masyarakat menjadi jauh lebih baik.

Berdasarkan informasi dari Gusri Efendi, bahwa ada dua belas (12) orang yang menanamkan modalnya melalui usaha wisata bahari/tirta ini yaitu Mahendri Watersport milik
Mahmud, Langit Watersport milik Jon, A5 Watersport milik Kobe Alhadi, Mutiara Bahari milik Islamudin, Dua Putra Watersport milik Rudi, CML Watersport milik Cia, Reta Watersport milik Rino, Neista Watersport milik Tosman, W4 Watersport milik Fauzi, Cingkuak Island Watersport milik Cei, Fg Watersport milik Hendrik, dan Resas Watersport milik Eko. Sementara untuk jasa odong-odong laut ada 2 orang pengelola yaitu Zaljabung dan Kobe Alhadi serta ada sekitar 30 orang yang juga merangkap sebagai penyedia jasa foto underwater di Pulau Cingkuak. Sementara di Pulau Setan juga terdapat usaha wisata tirta layaknya di Pulau Cingkuak yang merupakan cabang usaha tirta milik Mahmud, Cia dan Tosman.

Sejauh ini pariwisata pulau yang melibatkan hal-hal berupa menanamkan modal atau uang sudahterlaksana di Pulau Cingkuak, Pulau Setan, Pulau Cubadak, Pulau Kapo-Kapo, Pulau Pagang, dan Pulau Swarnadwipa. Pulaupulau tersebut dikelola untuk usaha di bidang daya tarik wisata bahari dan dikelola untuk usaha pariwisata dalam bidang penyediaan akomodasi dipulau seperti cottage, resort, homestay atau penginapan biasa serta usaha jasa makanan dan minuman di destinasi pariwisata dan juga sebagai tempat berenang dan bersinggah atau sebagai tempat berfoto bagi wisatawan. Untuk Pulau Sironjong Ketek memiliki daya tarik untuk cliift jumping karena ketinggian batuannya mencapai lebih dari 20 meter diatas permukaan laut dengan fasilitas semacam tali tambang untuk mencapai tempat tertinggi yaitu 20 meter diatas permukaan laut atau yang dapat disanggupi oleh wisatawan yang ingin melompat dari atas pulau tersebut tanpa ada daratan untuk berpijak.

Dari hasil penelitian yang penulis lakukan, dalam pelaksanaan terkait perizinan dipulau-pulau yang dimasuki modal oleh investor dalam negeri tak semuanya memiliki izin. Hasil temuan dilapangan melalui wawancara dengan beberapa investor yaitu dengan Gusri mewakili Mahmud, Cia, dan Kobe Alhadi menyatakan dan mengakui bahwa mereka tidak pernah mengurus izin apapun 
untuk melaksanakan usaha di bidang wisata bahari ini, mereka berdalih bahwa mereka sudah lama menjalankan usaha ini dan mereka merupakan masyarakat hukum adat di wilayah tersebut sehingga tak lagi perlu mengurusi izin.

Hal ini sesuai dengan Pasal 22 ayat (1) Undang-Undang Nomor 1 Tahun 2014 tentang Perubahan atas Undang-Undang no 27 Tahun 2007 tentang Pengelolaan Wilayah Pesisir dan Pulau-Pulau kecil. Dalam pasal tersebut dijelaskan bahwa "(1) kewajiban memiliki izin sebagai mana yang dimaksudkan dalam Pasal 16 ayat (1) dan Pasal 19 ayat (1) dikecualikan bagi Masyarakat Hukum Adat." Pasal 16 ayat (1) dan Pasal 19 ayat (1) yang dimaksudkan adalah izin lokasi dan izin pengelolaan dalam pemanfaatan dan pengelolaan perairain pesisir dan pulau-pulau kecil.

Namun menurut Isfildi, usaha pariwisata di Pesisir Selatan ada yang memiliki sudah memiliki izin, ada yang sedang mengurusi izin dan ada yang tidak memiki izin. Kebanyakan usaha daya tarik wisata atau kawasan wisata untuk wisata bahari seperti beberapa di Pulau Cingkuak dan Pulau Setan memang masih belum mengurusi izin. Begitu juga dengan usaha jasa transportasi pariwisata, kapal-kapal untuk trasnportasi menuju pariwisata pulau beberapa sudah memiliki izin. Lain hal dengan usaha jasa akomodasi dipariwisata pulau, semua investor dibidang ini sudah pasti mengurusi perizinan untuk memulai usahanya. Kebanyakan yang tidak mengurus izin memang berdalih bahwa statusnya adalah masyarakat hukum adat, namun tetap dihimbau untuk melakukan permohonan izin untuk setiap usaha. Hal ini juga diperuntukkan untuk pengusaha pariwisata sendiri mengingat hakikatnya tujuan pemberian izin bagi masyarakat adalah untuk adanya kepastian hukum, adanya kepastian hak, serta sebagai alat bukti yang kuat bila suatu ketika terjadi snegketa atau perselisihan.

Pengelolaan pariwisata di Pulau Cubadak telah menjalankan kewajibannya sebagai badan hukum untuk melakukan tanggung jawab sosial perusahaannya oleh PT.Bintang Paradiso. PT. Bintang Paradiso turut serta dengan masyarakat dalam kegiatan sosial yang berguna bagi kepentingan Pesisir Selatan seperti turut membantu dalam acara di wilayah setempat baik menjadi sponsor atau donatur atau bahkan ikut andil langsung dalam kegiatan serta memperkerjakan masyarakat di bidang usaha akomodasi pariwisatanya tersebut. Diketahui melalui Isfildi bahwa hanya sekitar 4 orang asing yang turut mengelola perusahaan tersebut dibidang ahli yang tidak dapat dilakukan oleh masyarakat lokal selebihnya perusahaan itu memperkerjakan masyarkat lokal.

Hal ini sesuai dengan Pasal 74 ayat (1) Undang-Undang NO.40 Tahun 2007 tentang Perseroan Terbatas yang berbunyi:

“(1) perseroan yang menjalankan kegiatan usahanya dibidang dan/atau berkaitan dengan sumber daya alam wajib melaksanakan tanggung jawab sosial dan lingkungan."

Begitu juga dengan Pasal 15 UndangUndang No. 25 Tahun2007 tentang Penanaman Modal bahwa:

"setiap penanam modal berkewajiban:

a. menerapkan prinsip tata kelola perusahaan yang baik;

b. Melaksanakan tanggung jawab sosial perusahaan;

c. Membuat laporan tentang kegiatan penanaman modal dan menyampaikannya kepada Badan Koordinasi Penanaman Modal;

d. Menghormati tradisi budaya masyarakat sekitar lokasi kegiatan usaha penanaman modal; dan

e. Mematuhi semua ketentuan peraturan perundang-undangan.

2. Kendala yang dihadapi dalam Pelaksanaan Pengelolaan Investasi dalam Sektor Pariwisata Pulau-Pulau Kecil di Kabupaten Pesisir Selatan Serta Solusi Dalam Mengatasi Kendala Tersebut

Pelaksanaan investasi di sektor pariwisata telah di atur dalam berbagai peraturan perundang-undangan sampai dengan peraturan darah dan keputusan bupati/walikota setempat. Dalam pelaksanaannya, terdapat kendala dalam pengelolaan investasi di bidang pariwisata pulau-pulau kecil di Pesisir Selatan ini beserta solusinya, yang dijabarkan sebagai berikut: 
1. Banyaknya Tanah Yang Tidak Terdaftar

Kesulitan yang pertama di bidang penanaman modal adalah ketidakjelasan mengenai tanah yang tidak terdaftar sehingga tidak memiliki sertifikat hak atas tanah sebagai bukti kepemilikan yanah tersebut namun dikuasai oleh masyarakat setempat. Hal ini menyebabkan tanah sulit untuk dikelola dengan secara maksimal jadi terhambat karena ketidakjelasan terhadap kepemilikan tanah tersebut.

Selain itu pengakuan dari banyaknya orang atau kaum yang mengakui bahwa mereka memiliki suatu tanah tersebut sehingga membuat bukti yang ada jadi tidak kuat atau bahkan tidak memiliki bukti. Dari hal ini bahkan bisa memunculkan banyak konflik baik bagi sesama masyarakat, antar masyarakat dengan pemerintah maupun antar masyarakat dengan investor.

Terkait pengakuan hak milik atas tanah oleh masyarakat ini bertentangan dengan Pasal 23 Undang-Undang No.5 Tahun 1960 tentang Pokok-Pokok Dasar Agraria yang berbunyi:

“(1) Hak milik, demikian pula setiap peralihan, hapusnya dan pembebanannya dengan hak-hak lain harus didaftarkan menurut ketentuan-ketentuan yang dimaksud dalam pasal 19.

(2) pendaftaran yang termaksud dalam ayat (1) merupakan alat pembuktian yang kuat mengenai hapusnya hak milik serta sahnya peralihan dan pembebanan hak tersebut."

Dalam hal ini solusi yang harus dilakukan oleh para pemilik tanah adalah melakukan pendaftaran tanah agar memiliki kepastian hukum yang kuat serta juga dapat di peruntukan sebagai alat pembuktian dalam kepemilikan tanah tersebut. Sesuai dengan Pasal 19 ayat (1) Undang-Undang Nomor 5 Tahun 1960 tentang Pokok Pokok Dasar Agraria bahwa:

"untuk menjamin kepastian hukum oleh pemerintah diadakan pendaftaran tanah diseluruh wilayah Republik Indonesia menurut ketentuan-ketentuan yang diatur dengan peraturan pemerintah"
2. Calon InvestorYang Tidak Memenuhi Persyaratan Yang Telah Di Tentukan

Pengurusan izin di investasi baik dibidang pariwisata maupun di bidang lainnya terkendala dari calon investor. Para calon investor cenderung lama dalam mengurus segala persyaratan yang diminta oleh DPMPPTSP Pesisir Selatan sehingga proses untuk mendapatkan izin menjadi tertunda.Hal ini juga terjadi karena sikap calon investor yang tidak serius ingin menanamkan modalnya di Pesisir Selatan.

Sementara itu dalam Pasal 26 ayat (1) Undang-Undang No. 25 Tahun 2007 Tentang Penanaman Modal menjelaskan bahwa:

“(1) Pelayanan terpadu satu pintu bertujuan membantu penanam modal dalam memperoleh kemudahan pelayanan, fasilitas fiskal, dan informasi mengenai penanaman modal."

Dalam hal ini pemerintah daerah memberikan solusi dengan SOP pelaksanaan pelayan perizinan dan non perizinan yang dilimpahkan kepada DPMPPTSP Pesisir Selatan Sesuai dengan Keputusan Bupati Pesisir Selatan Nomor:570/285/Kpts/BPTPS/2017 tentang Penetapan Standar Operasional Prosedur (SOP) Pelayanan Perizinan dan Non Perizinan Pada Dinas Penanaman Modal dan Pelayanan Perizinan Terpadu Satu Pintu Kabupaten Pesisir Selatan telah memberikan estimasi terhadap jangka waktu penyelesaian izin yaitu berkisar antara 2 (dua) sampai 7 (tujuh) hari kerja sepanjang persyaratan yang diberikan oleh pemohon izin lengkap dan benar.

3. Kurangnya Kesadaran Masyarakat Akan Pengembangan Kegiatan Penamaman Modal Terutama Di Sektor Pariwisata

Terkait kesadaran masyarakat banyak sekali kendala. Mulai dari antar investor dengan masyarakat kemudian tentang pemikiran masyarakat yang masih belum siap untuk kegiatan pariwisata serta yang masih terlalu memikirkan keuntungan pribadi. Biaya transportasi akomodasi dan makanan yang cenderung mahalnamun bukan didestinasi pariwisata atau dengan 
kata lain di hal yang berperan sebagai penunjang pariwisata. Hal itu cukup menghambat investor masuk juga wisatawan untuk kembali berwisata di Pesisir Selatan.Kendala juga terjadi karena pemikiran masyarakat yang masih awam dengan standar pemikiran apabila investor masuk ke daerahnya terutama untuk mengelola pariwisata maka akan terjadi penurunan terhadap perekonomiannya, padahal dalam Pasal 3 ayat (2) UndangUndang No.25 Tahun 2007 Tentang Penanaman Modal menjelaskan bahwa:

"(2) tujuan penyelenggaran penanaman modal, antara lain untuk:

a. Meningkatkan pertumbuhan ekonomi nasional;

b. Menciptakan lapangan kerja;

c. Meningkatkan pembangunan ekonomi berkelanjutan;

d. Meningkatkan kemampuan daya saing dunia usaha nasional;

e. Meningkatkan kapasitas dan kemampuan teknologi nasional;

f. Mendorong pengembangan ekonomi kerakyatan;

g. Mengolah ekonomi potensial menjadi kekuatan ekonomi riil dengan menggunakan dana yang berasal baik dari dalam negeri maupun luar negeri; dan

h. Meningkatkan kesejahteraan masyarakat.

Dalam Undang-Undang No. 10 Tahun 2009 tentang Kepariwisataan juga menjelaskan tentang pemerintah dan pemerintah daerah mendorong penanaman modal dalam negeri dan penanaman modal asing di bidang kepariwisataan dengan tujuan sesuai Pasal 4 Undang-Undang No.10 Tahun 2009 tentang Kepariwisataan, bahwa:

"Kepariwisataan bertujuan untuk:

b. Meningkatkan pertumbuhan ekonomi;

c. Meningkatkan kesejahteraan masyrakat;

d. Menghapus kemiskinan;

e. Mengatasi pengangguaran;

f. Melestarikan alam,lingkungan, dan sumberdaya alam;

g. Memajukan kebudayaan;

h. Mengangkat citra bangsa; i. Memupuk rasa cinta tanah air;

j. Memperkukuh jati diri dan kesatuan bangsa; dan

k. Mempererat persahabatan antar bangsa. Mengatasi kendala ini adalah peran pemerintah daerah untuk memberikan penyuluhan dan pendidikan pada masyarakat di Pesisir Selatan. Dalam BAB VIII Pasal 47 Undang-Undang No 27 Tahun 2007 Pengelolaam Wilayah Pesisir dan Pulau-Pulau Kecil menyatakan bahwa:

"Pemerintah menyelenggarakan pendidikan, pelatihan, dan penyuluhan pengelolaan wilayah pesisir dan pulau-pulau kecil untuk meningkatkan pengembangan sumber daya manusia di bidang pengelolaan wilayah pesisir dan pualu-pulau kecil, sesuai dengan peraturan perundang-undangan."

Terkait penyuluhan dan pelatihan ini juga diatur dalam undang-undang kepariwisataan lengkap dengan standarisasi dan sertifikasinya. Pasal 52 Undang-Undang No.10 Tahun 2009 Tentang Kepariwisataan yang menyatakan bahwa, "Pemerintah dan Pemerintah Daerah menyelenggarakan pelatihan sumber daya manusia pariwisata sesuai dengan ketentuan peraturan perundangundangan."

4. Minimnya Prasarana di Pesisir Selatan

Kendala selanjutnya berasal dari prasarana, bagi penulis dan kebanyakan wisatawan prasarana umum yang terdapat di Pesisir Selatan terutama prasarana menuju destinasi pariwisata masih belum memenuhi standar yang baik. Kondisi jalan yang cenderung buruk serta listrik untuk fasilitas umum dalam perjalanan menuju destinasi pariwisata juga tidak terlalu baik. Baik menuju destinasi pariwisata atau di tempat destinasi pariwisata yang juga menjadi kendala besar adalah sampah yg berada tidak pada tempatnya.

Solusi atas kendala ini baiknya ada koordinasi antar lembaga atau pemerintah untuk memperbaiki sarana/prasarana. Hal ini diatur dalam Pasal 33 Undang-Undang No. 10 Tahun 2009 Tentang Kepariwisataan bahwa:

“(1) Dalam rangka meningkatkan penyelenggaraan kepariwisataan pemerintah 
melakukan koordinasi strategis lintas sektor pada tatanan kebijakan, program, dan kegiatan kepariwisataan.

(2) Koordinasi strategis lintas sektir sebagaimana dimaksud paa ayat (1) meliputi:
a. bidang pelayanan kapebeanan, keimigrasian, dan karantina;
b. bidang keamanan dan ketertiban;
c. bidang prasarana uum, telekomunikasi, dan kesehatan lingkungan;
d. bidang transportasi darat, laut, dan udara;
e. bidang promosi pariwisata dan kerjasama luar negeri."

Ketentuan mengenai koordinasi strategis bidang prasarana umum dilakukan dengan instansi pemerintah dalam hal ketersediaan dan keterpeliharaan:
a. prasarana jalan menuju dan di lingkungan destinasi pariwisata;
b. air bersih untuk fasilitas umum dan fasilitas di destinasi pariwisata;
c. listrik untuk fasilitas umumdan fasilitas di destinasi pariwisata;
d. sarana telekomunikasi untuk fasilitas umum dan fasilitas pariwisata di destinasi pariwisata; dan
e. sistem pembuangan air kotor, sampah, dan sakitasi.
Terhadap hal yang sudah tersebut secara eksplisit dalam peraturan perundang-undangan diharapkan semua instansi terkait dapat mengerjakan tugasnya masing-masing untuk memperbaiki dan mengembangkan prasarana di Pesisir Selatan menjadi lebih baik lagi. Tidak hanya oleh pemerintah setempat namun oleh wisatawan serta pengusaha pariwisat juga harus ikut bekerjasama menjaga dan membantu memperbaharui prasarana yang ada.

\section{Kesimpulan}

1. Pelaksanaan investasi pariwisata pulau di Kabupaten Pesisir Selatan telah dilaksanakan sesuai dengan UndangUndang Nomor 25 Tahun 2007 tentang Penanaman Modal hal ini juga terlihat dari jenis pelayanan yang diberikan oleh DPMPPTSP Pesisir Selatan terkait pelayanan perizinan dan non perizinan di
Pesisir Selatan yang berpedoman kepada Keputusan Bupati Pesisir Selatan Nomor:570/285/Kpts/BPT-PS/2017 tentang Penetapan Standar Operasi Prosedur (SOP) Pelayanan Perizinan dan NonPerizinan Pada Dinas Penanaman Modal Dan Pelayanan Perizinan Terpadu Satu Pintu Kabupaten Pesisir Selatan. Dalam bidang pariwisata dapat dilihat bahwa ada satu penanam modal asing dan lebih dari 12 orang penamam modal dalam negeri yang menanamkan modalnya di pulau pulau kecil di Pesisir Selatan. Bidang usaha pariwisata yang lakukan oleh investor adalah dalam usaha daya tarik wisata/kawasan pariwisata, jasa transportasi pariwisata, jasa makanan dan minuman serta usaha penyediaan akommodasi.

2. Dalam pelaksanaannya, pemerintah maupun masyarakat mengalami kendalaserta solusinya sebagai berikut: banyaknya tanah yang tidak terdaftar maka solusinya adalah himbauan untuk melakukan pendaftaran tanah guna kebutuhan pemilik tanah, calon investor yang tidak memenuhi persyaratan perizinan maka diberikan kemudahan dalam pelayan perizinan dan non perizinan di DPMPPTSP Pesisir Selatan, kurangnya kesadaran masyrakat akan pentingnya kegiatan penanamna modal terutama di sektor pariwisata maka upaya yang dapat dilakukan adalah memberikan pembinaan, penyuluhan dan pembinaan terhadap masyarakat, serta kendala yang terakhir adalah minimnya fasilitas prasarana di Pesisir Selatan maka solusinya adalah melakukan koordinasi strategis lintas sektor antar instansi pemerintahan agar memaksimalkan prasarana yang ada.

\section{Saran}

Berdasarkan hasil pembahasan yang telah dikemukakan, maka dapat disampaikan beberapa saran yaitu:

1. Bagi Pemerintah Kabupaten Pesisir Selatan hendaknya mempermudah segala urusan dan kebutuhan dan fasilitas sarana dan prasarana bagi investor yang akandatang terutama di sektor pariwisata yang sedang 
giatnya berkembang di Pesisir Selatan bukan hanya untuk menarik investor asing namun juga investor dalam negeri maupun local Pesisir Selatan sendiri. Dalam hal kegiatan investasi yang telah berjalan sebaiknya pemerintah tetap memerhatikan hal hal yang dibutuhkan baik sarana maupun prasaranan terutama yang hanya dikelola oleh masyarakat setempat. Menurut penulis pemerintah juga harus bekerjasama dengan masyarakat pengelola pariwisata untuk memajukan pariwisata di Pesisir Selatan. Kemudian dalam hal perizinan di usaha pariwisata baiknya pemerintah lebih sering menghimbau atau lebih tegas lagi kepada masyarakat untuk mengurus izin usahanya serta penyuluhan bahwa memiliki izin adalah suatu hal yang penting terutama sebagai alat bukti jika dikemudian hari terjadi sengketa atau perselisihan.

2. Pemerintah Kabupaten Pesisir Selatan hendaknya lebih giat lagi melakukan penyuluhan pembinan dan pendidikan untuk masyarakat baik itu untuk pendaftaran tanah, pengurusan izin maupun untuk kesadaran untuk berusaha di bidang pariwisata serta penanaman modal. Serta baiknya ada pola komunikasi yang baik antara DPMPPTSP Pesisir Selatan dengan para pemohon izin sehingga pengurusan izin jadi lebih cepat dan baik. Terakhir untuk kendala di minimnya prasarana baiknya instansi terkait segera memperbaiki prasaran tersebut terutama dalam hal kondisi jalah yang buruk serta ketersediaan listrik umum dan juga kesehatan lingkungan seperti sampah baik di darat maupun diperairan, baiknya di perbanyak baliho/spanduk himbauan menjaga kebersihan serta ditambah dengan peran pengelola di destinasi wisata untuk menegur wisatawan apabila kedapatan membuang sampah sembarangan.

\section{DAFTAR PUSTAKA}

Kitab Undang-Undang Hukum Perdata

Undang-Undang no.25 tahun 2007 tentang Penanaman Modal
Undang-Undang Nomor 10 Tahun 2009 Tentang Kepariwisataan

Undang-Undang Nomor 27 Tahun 2007 Tentang Pengelolaan Wilayah Pesisir dan Pulau-Pulau Kecil

Undang-Undang Nomor 1 Tahun 2014 Tentang Perubahan Atas Undang-Undang Nomor 27 Tahun 2007 Tentang Pengelolaan Wilayah Pesisir dan Pulau-Pulau Kecil

Peraturan Pemerintah Nomor 45 Tahun 2008 Tentang Pedoman Pemberian Insentif dan Pemberian Kemudahan Penanam Modal di Daerah

Peraturan Daerah Kota Padang Nomor 11 Tahun2009 Tentang pemberian Insensif dan Pemberian Kemudahan Penanam Modal

Ahmadi Miru.2013.Hukum Kontrak:Perancangan Kontrak. Jakarta:Rajawali Pers.

Amiruddin dan Zainal Asikin. 2003.Pengantar Metode Penelitian Hukum. Jakarta:Raja GrafindoPersada.

Ammirudin Ilmar. 2010.Hukum Penanaman Modal di Indonesia. Jakarta:Kencana.

Bambang Sunggono. 2009.Metodologi Penelitian Hukum.Jakatrta:Rajawali Pers.

Departemen Pendidikan dan Kebudayaan RI. Kamus Besar Bahasa Indonesia(KBBI). Jakarta: Balai Pustaka.

Direktori Objek dan Atraksi Wisata Sumatera Barat. 2017. Dinas Pariwisata Sumbar

Ida Bagus Rachmadi Supacana.2006.kerangka Hukum dan Kebijakan Investasi Langsung di Indonesia.Jakarta:Ghalia Indonesia.

Kencana. 2009.Pengantar Ilmu Pariwisata. Bandung:Mandar Maju.

Salim Hs dan Budi Sutrisno .2012.Hukum Investasi di Indonesia.Jakarta: Rajawali Pers.

Sentosa Sembiring. 2007.Hukum Investasi. Bandung: CV. Nuansa Ullia.

Siska Elvandari.2015.Hukum Penyelesaian Sengketa Medis. Yogyakarta: Thafa Media. 
Violetta Simatupang. 2009.Pengaturan Hukum

Kepariwisataan Indonesia. Bandung: Alumni.

Biro Humas Provinsi Sumatera Barat.Lagi Wagub Sumbar Tekankan Pengembangan Pariwisata Sumbar. Tersedia di www.sumbarprov.go.id/details/news/703 0 diakses pada 1 Oktober 2019 pada jam 16.07 wib

Faurani Santi.Faktor-faktor Penentu Aliran Permintaan dan Penawaran Investasi Barang. Jasa Pariwisata Indonesia.jurnal Buletin Ekonomi Moneter dan Perbankan-Januari 2010.

Sefira Ryalita Primadani dkk. Analisis Strategi Pengembangan Pariwisata Daerah (Studi pada Dinas Kebudayaan dan Pariwisata Daerah Kabupaten Nganjuk). Jurnal Administrai Publik (JAP) Vol1 No.4

Sekretariat DPRD Prov.Sumbar.Pemprov Ajukan Ranperda Zonasi wilayah Pesisir ke DPRD. Tersedia di www.sumbarprov.go.id/details/news/110 $\underline{38}$

Junisman.Pessel kembangkan 47 pulau sebagai kawasan wisata dan konservasi. Tersedia di http://berita.pesisirselatankab.go.id 